\title{
PUBLIKACJE
}

Alicja Jagielska-Burduk

\section{Informacja o książce \\ Katarzyny Zalasińskiej \\ Ustawa o ochronie zabytków \\ i opiece nad zabytkami. Komentarz}

ISBN 978-83-8198-718-9

Wydawnictwo C.H. Beck, Warszawa 2020

Publikacja Katarzyny Zalasińskiej Ustawa o ochronie zabytków i opiece nad zabytkami. Komentarz stanowi najbardziej aktualne kompendium wiedzy o obowiązującej ustawie i jej stosowaniu. Na rynku dostępnych jest już kilka komentarzy do ustawy z 23 lipca 2003 r. o ochronie zabytków i opiece nad zabytkami (tekst jedn. Dz. U. z 2021 r., poz. 710, 954), jednak w związku z kolejnymi nowelizacjami ustawy zdezaktualizowały się. Publikacja wydana nakładem Wydawnictwa C.H. Beck w 2020 r. uwzględnia zarówno zmiany prawne, jakie miały miejsce w ostatnich latach, jak i dynamicznie rozwijającą się doktrynę prawa ochrony zabytków oraz orzecznictwo sądów administracyjnych.

Komentarz liczy 378 stron i dotyczy systemowych zmian wprowadzonych do ustawy po 2017 r. Autorka podejmuje kluczowe problemy interpretacyjne związane z nowymi przepisami, jak i tymi obowiązującymi od 2003 r. Jednocześnie w klarowny sposób tłumaczy złożoność praktyki organów ochrony zabytków.

Komentarz zawiera szczegółowe omówienie przepisów ustawy z 23 lipca 2003 r. o ochronie zabytków i opiece nad zabytkami, z uwzględnieniem: 
- ustawy z 22 czerwca 2017 r. o zmianie ustawy o ochronie zabytków i opiece nad zabytkami oraz niektórych innych ustaw (Dz. U. poz. 1595),

- ustawy z 16 kwietnia 2020 r. o zmianie ustawy Prawo geodezyjne i kartograficzne oraz niektórych innych ustaw (Dz. U. poz. 782), która wprowadza zmiany wynikające $z$ usunięcia obowiązku gromadzenia w ewidencji gruntów i budynków informacji o wpisaniu do rejestru zabytków,

- ustawy z 19 lipca 2019 r. o zapewnianiu dostępności osobom ze szczególnymi potrzebami (Dz. U. poz. 1696), która wprowadziła obowiązek uwzględniania w dokumentacji konserwatorskiej analizy możliwości adaptacji obiektu zabytkowego, także pod kątem dostosowania go do potrzeb osób ze szczególnymi potrzebami,

- ustawy z 22 listopada 2018 r. o zmianie ustawy Prawo oświatowe, ustawy o systemie oświaty oraz niektórych innych ustaw (Dz. U. poz. 2245), która wprowadza drobną zmianę pojęciową w przepisie dotyczącym kwalifikacji osób zatrudnionych przy zabytkach będących parkami,

- ustawy z 21 lutego 2019 r. o zmianie niektórych ustaw w związku z zapewnieniem stosowania rozporządzenia dotyczącym RODO (Dz. U. poz. 730), która miała na celu określić na poziomie ustawowym precyzyjny i zamknięty katalog danych osobowych przetwarzanych w rejestrach publicznych, tj. rejestr zabytków, ewidencja zabytków, krajowy wykaz zabytków skradzionych lub wywiezionych za granicę niezgodnie z prawem.

W książce Ustawa o ochronie zabytków i opiece nad zabytkami. Komentarz znaleźć można odniesienia do orzecznictwa administracyjnego w zakresie ochrony zabytków. Zostało ono przez autorkę starannie wyselekcjonowane i uporządkowane, tak aby przedstawić czytelnikowi pełny obraz aktualnego dorobku judykatury i zmiany, jakie w nim zaszły. Autorka odwołuje się do literatury przedmiotu polskiej i zagranicznej.

Publikacja jest adresowana zarówno do praktyków, w tym prawników, urzędników, jak i właścicieli i posiadaczy zabytków. Stanowi również cenny punkt odniesienia dla osób zajmujących się ochroną zabytków na polu naukowym.

Nie ulega wątpliwości, że połączenie rozważań teoretycznych z praktyką, w tym z doświadczeniem, jakie zdobyła autorka, pełniąc funkcję Dyrektora Departamentu Ochrony Zabytków Ministerstwa Kultury, Dziedzictwa Narodowego i Sportu, sprawia, że publikacja może stanowić drogowskaz dla podmiotów stosujących prawo. 